\title{
PENERAPAN SELF-SUFFICIENT PADA REDESAIN RUMAH SUSUN KEBON KACANG
}

\author{
Silvia ${ }^{1)}$, Fermanto Lianto ${ }^{2)}$ \\ 1)Program Studi S1 Arsitektur Fakultas Teknik, Universitas Tarumanagara, silvandretti12@gmail.com \\ 2) Program Studi S1 Arsitektur Fakultas Teknik, Universitas Tarumanagara, fermantol@ft.untar.ac.id
}

\begin{abstract}
Abstrak
Rumah menjadi tempat yang paling aman untuk menghindari Covid-19, tetapi perbedaan kehidupan masyarakat yang tinggal di rumah tapak dengan rumah susun sangatlah berbeda. Kehidupan masyarakat yang berubah drastis dari segala aspek, yakni aspek kesehatan, ekonomi, sosial, dan lainnya. Dimana kondisi Covid-19 ini mengharuskan masyarakat untuk secara temporari menghentikan aktivitas normal sampai tidak tahu lamanya. Hal ini dapat dilakukan dengan cara meredesain rumah susun yang sudah berusia tua, misalnya rusun Kebon Kacang. Selain umur bangunan sudah tua, rusun ini juga sudah semakin kumuh, belum lagi letaknya yang strategis di tengah-tengah kota yang seharusnya dapat menjadi potensi. Dengan membangun proyek redesain rumah susun Kebon Kacang khususnya ditujukan untuk penghuni rumah susun dengan menawarkan fasilitas-fasilitas untuk memenuhi aktivitas dan kebutuhan sehari-hari mereka, serta sistem untuk menghindari Covid-19. Selain itu dengan redesain cenderung berperan penting terhadap lingkungan, selain menyediakan kebutuhan untuk penghuni sehingga tidak perlu melakukan perjalanan, ini juga berdampak terhadap ekologi, seperti kualitas udara yang meningkat akibat berkurangnya penggunaan kendaraan bermotor. Dengan menggunakan metode penelitian deskriptif analisis, studi literatur dan studi kasus, dan metode perancangan self-sufficient yang bertujuan agar bangunan dan penghuni dapat saling produktif serta mengubah kebiasaan penghuni menjadi lebih mandiri terkait pandemik Covid-19. Penerapan self-sufficient pada proyek meliputi rainwater harvesting, food production, green roof, serta green balcony. Pada redesain rumah susun kebon kacang ini menawarkan program hunian, komersial seperti food market, foodcourt, café/coffee shop dan kios, pendidikan untuk anak, fasilitas-fasilitas seperti hidroponik, gym, taman bermain, dan lainnya.
\end{abstract}

Kata kunci: Covid-19; hunian; mandiri; redesain; rumah susun

\section{Abstract}

House is the safest place to avoid Covid-19. The lives of people who live in landed houses and flats are different. People's lives have changed drastically from all aspects, namely health, economic, social, and other aspects. This Covid-19 condition requires people to stop doing normal activities temporarily. This condition can be done by redesigning old flats as a solution, such as the Kebon Kacang flats. In addition to being old, this flat is also getting shabby, not to mention its strategic location in the middle of a city that should have potential. Kebon Kacang flats project aims explicitly at the residents of the flats by offering facilities to fulfill their daily activities and needs to avoid Covid-19. In addition, redesign tends to play an essential role in the environment, such as providing needs for residents so that they do not need to travel. These also impact ecology, such as increased air quality due to the reduced use of motorized vehicles. Using analytical descriptive research methods, literature studies and case studies, and the self-sufficient design methods approach aims to make the building and occupants mutually productive and create a new sufficient habit due to this pandemic. Self-sufficient application in this project involves rainwater harvesting, food production, green roof, and green balcony. The redesign of the Kebon Kacang flats offers residential, commercial programs such as food markets, food courts, cafes/coffee shops and kiosks, education for children, facilities such as hydroponics, gyms, playgrounds, and others.

Keywords: Covid-19; flats; house; redesign; self-sufficient 


\section{PENDAHULUAN}

Pada awal tahun 2020, pandemi kembali menyerang seluruh permukaan bumi dengan virus baru yang awalnya ditemukan di salah satu kota di China. Virus SARS-Cov-2 atau yang lebih dikenal sebagai Covid19 ini berasal dari salah satu pasar basah di Wuhan, China. Pandemi adalah wabah penyakit menular yang menyebar luas dalam skala internasional bahkan sampai ke seluruh dunia (Porta, 2008). Pandemi Covid-19 ini dapat bergerak dengan cepat karena adanya kemajuan dari teknologi. Percepatan menjadi salah satu kemajuan yang dialami dalam dewasa ini, salah satunya percepatan teknologi. Covid-19 membawa perubahan ke dalam kehidupan sehari-hari manusia tidak perlahan-lahan, namun secara tiba-tiba dimana manusia tidak sama sekali melakukan persiapan.

Salah satu yang merespons dampak Covid-19 ini adalah arsitektur. Hal ini dikarenakan Covid-19 secara tidak sadar berusaha mengontrol manusia yang biasanya menjadi yang tidak biasanya. Sehari-harinya manusia berkegiatan di bawah sebuah arsitektur, entah itu rumah, sekolah, kantor, ataupun tempat hiburan. Dengan adanya sebuah kebijakan New Normal yang memperbolehkan sebagian pihak untuk beraktivitas normal dengan protokol kesehatan menjadikan sebuah tugas baru dalam bidang arsitektur tentang bagaimana membuat ruang untuk merespons keadaan yang sedang berlangsung ini.

Rumah menjadi tempat yang paling aman untuk menghindari Virus Covid-19. Khususnya dengan masyarakat yang tinggal di tempat yang cukup ramai dan berhimpitan satu sama lain, seperti apartemen, rumah susun sederhana, dan lainnya. Perlunya perubahan dalam sisi arsitektur dan sistemnya untuk hunian ini demi menghindari terjadinya penularan dan tetap memberi kenyamanan serta fasilitas-fasilitas yang mumpuni bagi penghuni. Seperti contoh pada rumah susun Kebon Kacang yang usianya sudah terbilang tua dan kondisi sudah tidak layak lagi. Berada di wilayah yang kumuh dan kurang bersih akan mempercepat penularan Covid-19. Belum lagi fasilitas yang kurang membuat penghuni harus tetap bepergian ke luar. Ini menjadi kekhawatiran bagi masyarakat. Pada kondisi eksisting penghuni rumah susun Kebon Kacang juga mengalami perubahan, di mana penghuni yang sekarang dengan kondisi finansial menengah ke atas. Tentunya hal ini diiringi dengan perubahan struktur sosial dan gaya hidup penghuni.

Oleh sebab itu, perlunya redesain pada rumah susun Kebon Kacang untuk memberi penghuninya kenyamanan dan menyediakan fasilitas retail/komersil yang memudahkan penghuni untuk memenuhi kebutuhan hidupnya serta mempersempit resiko terjadinya Covid-19 karena tidak melakukan perjalanan ke luar dapat menjadi solusi penting. Hal positif yang didapat juga berkurangnya penggunaan kendaraan motor yang berdampak pada kualitas udara.

Beberapa hal yang ingin diatasi akibat pandemi Covid-19 terhadap hunian rumah susun Kebon Kacang ini (Redesain) adalah sebuah adaptasi terhadap aktivitas baru masyarakat dan respons arsitektur dalam menghadapi Covid-19. Menangani Covid-19 sangat penting bagi masyarakat, baik dari aspek kesehatan, sosial, bahkan ekonomi yaitu dengan menurunkan dan menghindari resiko terpapar Covid19.

\section{KAJIAN LITERATUR}

\section{Beyond Ecology}

Ekologi adalah sebuah ilmu yang mempelajari tentang organisme di dalam suatu tempat dimana organisme tersebut hidup. Dalam arti lain dapat diartikan juga sebagai studi ilmu hubungan timbal balik antara organisme dan lingkungannya. Dengan demikian ekologi dapat disimpulkan sebagai ilmu dasar lingkungan yang mempelajari tentang makhluk hidup dan komponen di sekitarnya (Haeckel, 1866).

Ekologi berarti bahwa semua organisme dan alam memiliki utilitas dan fungsi masing-masing. Adanya keterkaitan satu dengan lainnya yang berarti bahwa jika adanya perubahan dari satu hal akan mempengaruhi hal lainnya. Seperti fenomena yang sedang kita rasakan saat ini, Covid-19 yang 
menyerang seluruh dunia membuat dampak dan perubahan drastis terhadap ekologi dan aspek lainnya. Hal ini membuat adanya keinginan untuk mengembangkan sumber daya dengan menggunakan teknologi, yang artinya disini untuk mencari solusi. Sebagai contoh, akibat dari polusi yang menyebabkan kualitas udara menurun, solusinya adalah dilusi.

Dengan percepatan yang kita alami sekarang, sangat memudahkan komunikasi, pergerakan, teknologi, informasi, dan lainnya. Seperti percepatan penyebaran Covid-19 akibat adanya percepatan pergerakan orang melalui teknologi informasi. Sehingga berakibat menjadi pandemi global. Ini yang disebut beyond. Dipengaruhi oleh dua hal yaitu speed and mobility dan speed and digital ecology.

\section{Covid-19}

Pada awal tahun 2020, munculnya coronavirus jenis baru yaitu SARS-CoV-2 atau yang lebih dikenal dengan COVID-19 (Coronavirus Diease 2019) (WHO, 2020). Virus yang berasal dari kota Wuhan, China yang terdeteksi pada awalnya pada akhir tahun 2019. Pada awalnya data epidemiologi menunjukkan $66 \%$ pasien yang pernah pergi ke sebuah pasar basah seafood di Wuhan, China (Huang, 2020).

Coronavirus bertransmisi melalui hewan ke manusia. Coronavirus bertransmisi melalui kelelawar yang menjadi sumber utama untuk fenomena SARS (Severe Acute Respiratory Syndrome) dan MERS (Middle East Respiratory Syndrome) (Perhimpunan Dokter Paru Indonesia, 2020). Coronavirus hanya dapat bereplikasi pada sel inangnya karena virus tidak dapat bereplikasi tanpa perantara.

Coronavirus merupakan virus tunggal positif RNA, yang memiliki ciri berkapsul serta tidak bersegmen. Termasuk dalam ordo Nidovirales, family Coronaviridae. Struktur coronavirus ini membentuk struktur seperti kubus dengan protein $\mathrm{S}$ yang terletak di permukaan virus. Protein utama virus disebut sebagai protein $S$ yang merupakan struktur utama dimana protein $S$ ini memiliki peran untuk penempelan dan masuknya virus ke dalam sel inang (Wang, Qiang, \& Ke, 2020).

Covid-19 yang menjadi pandemi mulai dari awal tahun 2020 ini tentunya memberi dampak dalam berbagai aspek kehidupan, yakni aspek kesehatan, apek sosial, dan terutama aspek ekonomi. Dampak kesehatan yang dirasakan masyarakat bukan hanya kesehatan secara fisik, namun juga kesehatan mental. Hal ini disebabkan oleh situasi yang tiba-tiba mengubah aktivitas dan pandangan masyarakat dan tanpa persiapan sehingga terjadilah kepanikan dan kegelisahan yang berlebihan (Brooks, et al., 2020). Sedangkan dalam aspek sosial, seperti tidak lagi berjabat tangan ketika bertemu, menjaga jarak dengan satu sama lain, tidak dapat bicara secara langsung melainkan dibatasi masker, dll (Bariah, 2020). Tapi juga hal-hal seperti dihimbau mencuci tangan lebih sering, menggunakan disinfektan, menjadi perubahan yang cukup baik akan kesadaran masyarakat terhadap kebersihan. Dan dalam aspek ekonomi sektor-sektor perdagangan, transportasi, pariwisata, jasa, dan lain-lain mengalami inflasi ekonomi dikarenakan tidak dapatnya beroperasi selama pandemi Covid-19 untuk menghindari menaiknya kasus Covid-19 (Susilawati, Falefi, \& Purwoko, 2020).

\section{Rumah Susun}

Rumah susun merupakan sebuah hunian vertikal di suatu lingkungan dimana rumah susun biasanya terbagi menjadi bagian-bagian terstruktur secara fungsional baik secara horizontal atau vertikal dimana setiap bagian dapat menjadi milik dan digunakan secara terpisah yang dilengkapi dengan bagian, benda, dan tanah bersama. (No. 16 UU tahun 1985 tentang rumah susun, pasal 1 ayat 1).

Pada kehidupan hunian vertikal rumah susun, karena adanya keterbatasan lahan sehingga menyebabkan keterbatasan ruang bagi penghuni. Misalnya terdapat taman pada bagian enterance sedangkan di lantai pertama terdapat area jalan. Walapun menurut aturan taman dan jalan dikategoriKan sebagai area komunal/bersama, namun jarak merupakan kendala utama akses bagi penghuni yang tinggal di lantai 2 ke atas, sehingga rasa kepemilikan penghuni terhadap area-area tersebut kurang (Ichwan, 2010). 
Ruang publik secara penataannya memiliki fungsi sebagai fasilitas pendukung dimana terjadinya interaksi sosial antar penghuni (Carmona, Tiesdell, Heath, \& Oc, 2003). Oleh sebab itu selasar pada rumah susun memiliki peran krusial karena fungsinya sebagai ruang publik. Tapi tanpa disadari bahwa dengan hadirnya selasar ini juga membuat pengelompokkan dari segi sikap akibat adanya keterbatasan ruang yang dibangun pada keterbatasan lahan ini. Ruang adalah hal penting yang dibutuhkan manusia untuk menjalani kehidupan sehari-hari. Dimana hunian merupakan kebutuhan utama yang paling penting untuk manusia tinggal yang memiliki zonasi ruang sebagai batas-batas antara area publik dan privat. Namun seringkali dalam ruang hunian mengalami pergeseran kebutuhan. Penghuni menjadi penyebab utama atas terjadinya pergeseran dan perubahan kebutuhan ruang ini. Ruang selasar sebagai contoh ruang yang seringkali mengalami perubahan dan pergeseran fungsi. Adaptasi dengan lingkungan sekitar menjadi hal yang sangat penting dalam kehidupan manusia (Ichwan, 2010).

\section{Self-Sufficient Building}

Sufficient didefinisikan sebagai sebuah ketergantungan sumber daya dan kemampuan internal yang digunakan untuk mencukupi kebutuhan (orang/masyarakat) dengan tujuan agar dapat hidup mandiri dengan sistem yang mandiri juga . Mandiri dalam arti kemampuan untuk mengatasi masalah sendiri. Tujuan untuk mencukupi kebutuhan dengan mengandalkan kemampuan dan sumber daya sendiri yang bersifat ekonomis. Dalam arsitektur, bangunan mandiri adalah bangunan yang dirancang agar hal-hal seperti energi listrik, pengolahan air, penyediaan makanan, dll secara infrastruktur dapat disediakan secara mandiri. Hal ini juga memberikan dampak positif terhadap lingkungan dan tentunya lebih ekonomis (Shang, 2009).

\section{Studi Kasus}

Dalam studi kasus akan membahas proyek hunian yang memiliki isu serupa yaitu Mass Timber Housing (gambar 1). Proyek ini di desain oleh arsitek yang berasal dari Barcelona yaitu Guallart Architects dalam kompetisi internasional untuk desain Mixed-use Communities di kota Xiong An, China. Mixed-use communities ini bertujuan untuk mendefinisikan standar baru di era pasca Covid-19 yang sedang menyerang seluruh dunia. Proyek ini memiliki konsep self-sufficient city dengan model perkotaan yang menggabungkan blok perkotaan tradisional Eropa, Menara modern China, dan lanskap pertanian produktif.

Mixed-use Communities ini merupakan solusi bagi orang untuk dapat hidup, bekerja, dan beristirahat, serta memungkinkan untuk penghuninya dapat menghasilkan sumber daya secara lokal, sehingga dapat memenuhi kebutuhan hidup mereka walaupun dalam keadaan yang tidak terduga, seperti karantina saat Covid-19.

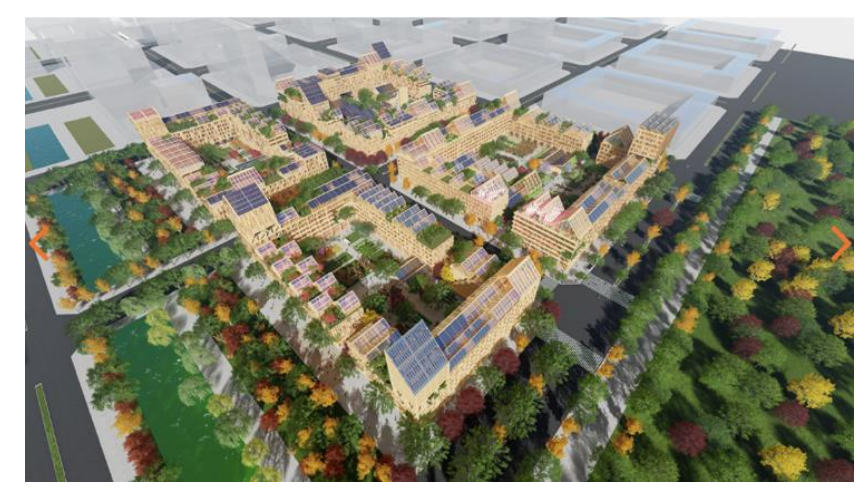

Gambar 1. Mass Timber Housing

Sumber: https://worldarchitecture.org, diakses 21 Maret 2021

Empat blok yang akan dibangun menggunakan mass timber dan solusi desain pasif dengan program apartemen, hunian untuk orang tua dan muda, perkantoran, kolam renang, retail, food market, taman 
kanak-kanak, pusat administrasi dan stasiun pemadam kebakaran serta fasilitas lainnya. Semua bangunan akan memiliki sistem untuk menghasilkan makanan agar dapat memenuhi kebutuhan sehari-hari penghuni, serta penggunaan atap miringnya untuk menghasilkan energi.

\section{METODE}

\section{Metode Penelitian}

Metode penelitian merupakan ilmu tentang cara melaksanakan penelitian yang didasarkan oleh fakta atau fenomena ilmiah. Secara umum terdapat tiga metode penelitian antara lain, metode penelitian kuantitatif, metode penelitian kualitatif, dan metode penelitian kombinasi. Metode penelitian yang digunakan penulis yaitu metode deskriptif, studi literatur, dan studi kasus (Creswell, 2013). Metode yang digunakan termasuk dalam metode penelitian kualitatif.

\section{a. Metode Deskriptif}

Dalam metode ini, peneliti mendeskripsi sebuah pengalaman terhadap suatu fenomena tertentu yang dialami manusia. Fenomena yang dideskripsikan penulis adalah mengenai virus Covid-19 yang menjadi pandemi dan membawa perubahan terhadap ekologi.

\section{b. Studi Literatur}

Teori yang digunakan dalam penulisan ini mengenai tentang ekologi, beyond ecology, Covid-19, rusunawa dan kehidupan masyarakat di rusunawa, serta Rusun.

\section{c. Studi Kasus}

Studi kasus merupakan penelitian dengan mencari pengetahuan yang menyelidiki fenomena terkait konteks tertentu yang terjadi secara nyata dalam kehidupan (Creswell, 2013). Studi kasus mengacu pada pengetahuan mengenai bangunan public housing dan bangunan yang beradaptasi dengan kondisi Covid-19.

\section{Metode Perancangan}

Dalam proyek redesain rumah susun Kebon Kacang menggunakan metode self-sufficient housing. Dimana kriteria dari pendekatan self-sufficient housing (de Garrido, 2012) yang ingin diterapkan meliputi:

a. Recycled Water

Menggunakan teknik rainwater harvesting untuk menampung air hujan dan diolah, kemudian dipakai kembali untuk menyiram tanaman.

b. Food Production

Menggunakan teknik hidroponik yang menggunakan tanah sebagai media tanam. Hidroponik dapat menggunakan pipa pvc, botol bekas, bahkan tembok sebagai media tanamnya. Pada proyek ini akan menerapkan tipe Nutrient Film Technique (NFT) di mana tujuannya untuk menghemat penggunaan tempat dan sirkulasi. Metode NFT ini membudidayakan tanaman dengan cara akarnya di tanam di lapisan yang dangkal sehingga dapat memperoleh oksigen yang cukup (Roidah, 2014).

c. Farming Landscape

Pada farming landscape menerapkan green roof.

d. Productive Balcony

Menerapkan penghijauan pada balcony masing-masing penghuni.

Tujuannya adalah untuk membentuk bangunan mandiri dan mendorong perubahan kebiasaan manusia. Dengan hal ini mampu untuk membuat penghuni lebih mudah beradaptasi dengan bangunan terutama saat kondisi pandemi Covid-19 ini. Gambar 2 di bawah merupakan contoh bangunan self sufficient. 


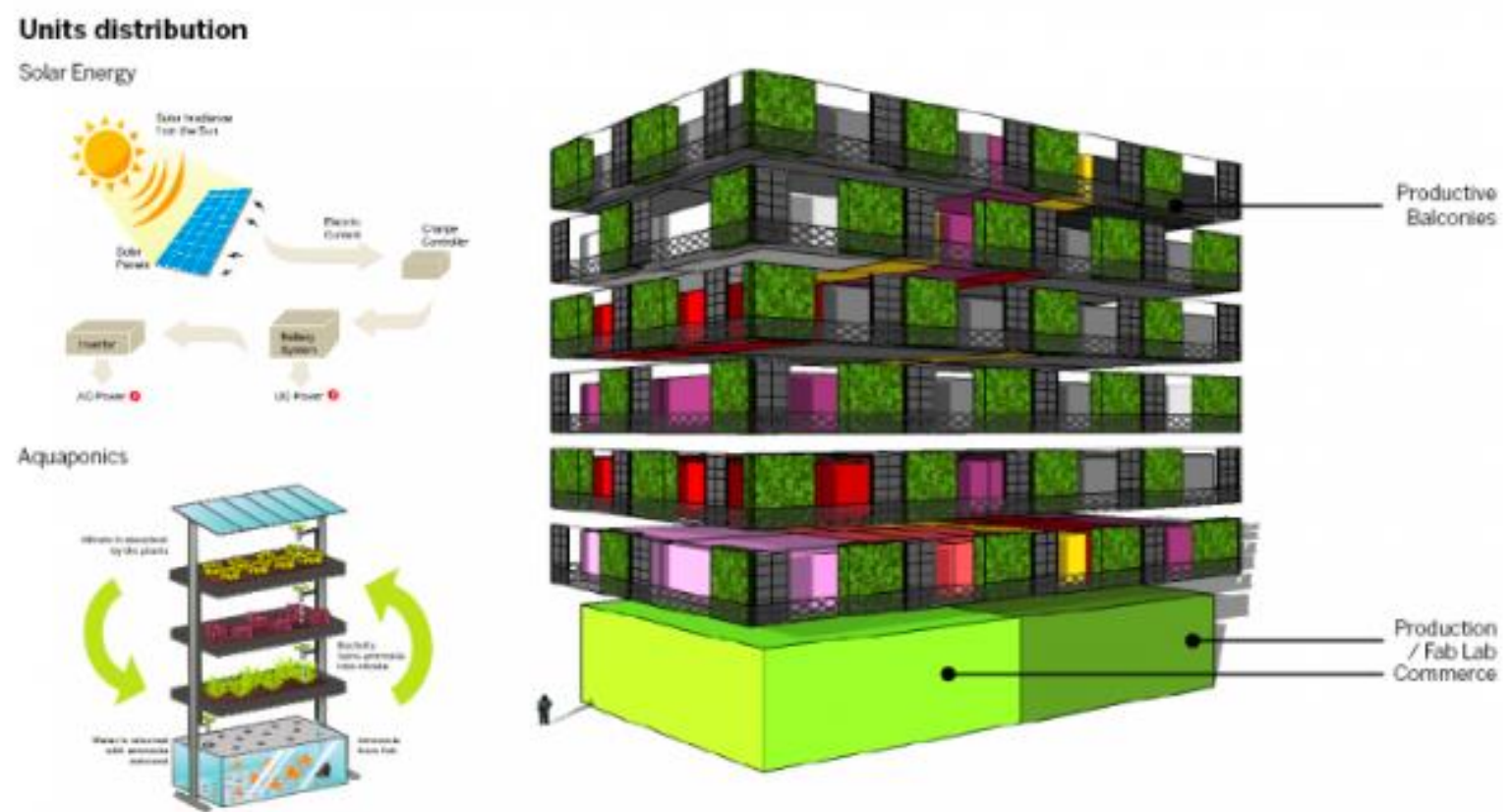

Gambar 2. Contoh bangunan self-sufficient

Sumber: http://www.iaacblog.com/programs/living-considerations-self-sufficient-building/, diakses 17 Februari 2021

\section{DATA TAPAK}

Rumah susun Kebon Kacang (gambar 3) memiliki potensi yang besar untuk di revitalisasi secara penuh dan diberi program yang lebih baik untuk meningkatkan kesejahteraan hidup masyarakat dan adaptasi baru masyarakat rusun dalam menghadapi Covid-19 ini. Memberikan wadah baru untuk masyarakat rusun untuk lebih aktif dan berkreasi secara efisien dan efektif dalam beraktvitas secara aman dalam kondisi pandemi Covid-19.

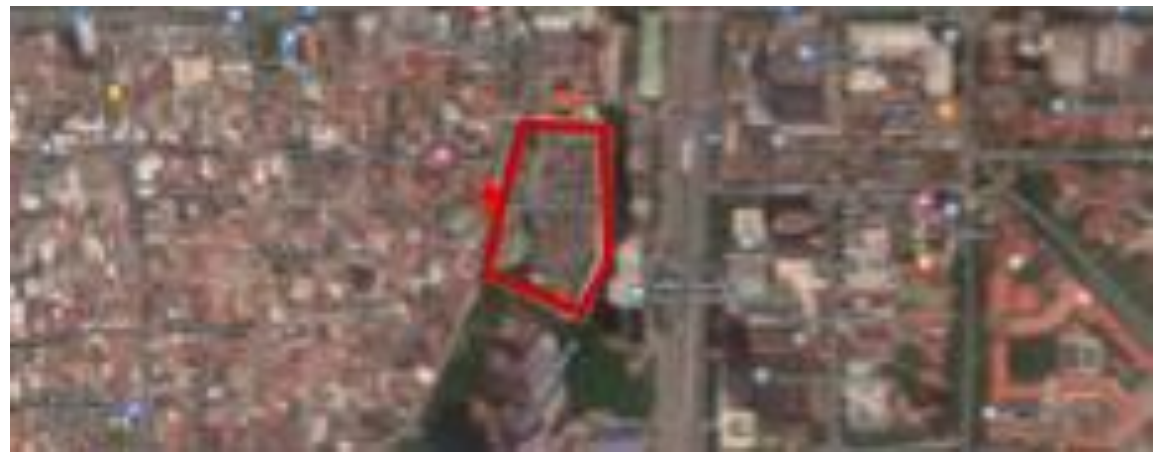

Gambar 3. Lokasi Tapak JI. Kebon Kacang XI

Sumber: google maps, diakses 2 Maret 2021

Zonasi Peruntukan: Zona Perumahan Vertikal (sub-zona rumah susun)

$\begin{array}{ll}\text { Luas Tapak } & : \pm 13.000 \mathrm{~m}^{2} \\ \text { KDB } & : 55 \%= \pm 7.150 \mathrm{~m}^{2} \\ \text { KDH } & : 30 \%= \pm 3.900 \mathrm{~m}^{2} \\ \text { KLB } & : 3= \pm 39.000 \mathrm{~m}^{2} \\ \text { KB } & : 8 \text { dan KTB: } 55\end{array}$




\section{DISKUSI DAN HASIL}

\section{Analisis Tapak}

Dari hasil analisis tapak pada sekitar kawasan Kebon Kacang terdapat beberapa hal seperti penghuni, aktivitas yang terjadi, fasilitas-fasilitas, dan aksesibilitas. Pada analisis penghuni rumah susun Kebon Kacang pada awalnya ditargetkan untuk MBR pada kawasan Kebon Kacang maupun pendatang. Seiring berjalannya waktu, karena berada di daerah segitiga emas, penghuni kebon kacang yang lama mulai pindah dan berganti dengan penghuni baru yang memiliki pendapatan di atas rata-rata. Penghuni menengah ke atas ini memilih untuk tinggal di rumah susun Kebon Kacang karena harga yang lebih murah serta letak yang strategis untuk mencapai pusat kota. Sehingga pada proyek redesain rumah susun Kebon Kacang ini berstandar menengah ke atas dan di targetkan untuk penghuni eksisting rumah susun.

Selanjutnya, aktivitas pada tapak di analisis dalam 3 waktu yang berbeda dan dibagi menjadi 3 kategori yaitu, tempat publik/titik berpencar (global), titik transit/sementara, dan tempat publik local (gambar 4). Pada tempat global itu biasanya pada tempat dimana semua orang keluar misalnya pada jam masuk kantor dan pulang kantor. Dimana pada titik tersebut merupakan titik berpencar semua orang. Pada tapak titik ini terdapat di nodes (perempatan jalan utama) pada pagi, siang dan sore hari. Tempat lainnya adalah pusat komersial. Sedangkan titik transit terdapat pada tempat pemberhentian kendaraan umum. Dan titik publik lokal terdapat pada lingkungan PKL, masjid/musholla, dan lain-lain.
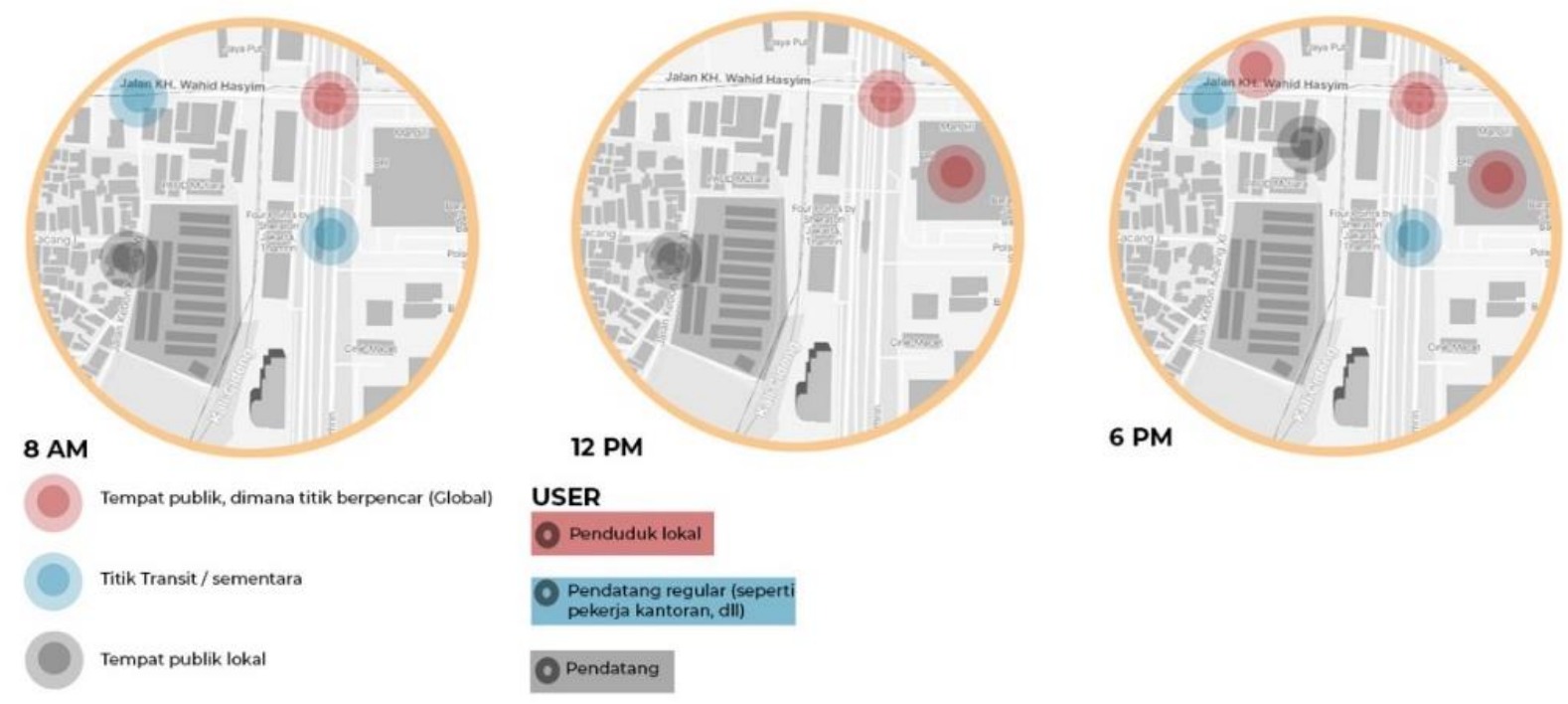

Gambar 4. Aktivitas sekitar tapak

Sumber: google maps, dielaborasi, diakses 30 Maret 2021

Pada gambar 5, sekitar tapak terdapat beberapa fasilitas dari kegiatan komersial/ekonomi yang diliputi pasar dan mall. Kemudian ruang terbuka hijau yang diliputi taman serta TPU. Fasilitas pendidikan mulai dari TK-SD-SMP-SMA. Selanjutnya ada fasilitas pemerintahan dan tempat ibadah yang didominasi masjid/musholla dan diiringi beberapa gereja. 


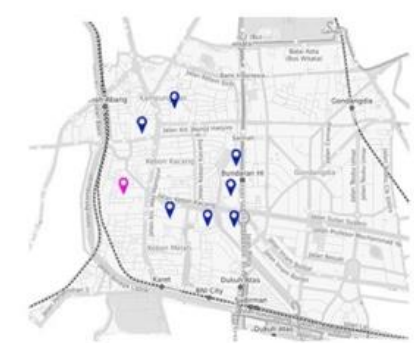

KOME:RSIAL. / KEGIATAN EKONOMI 9 PASAR
P

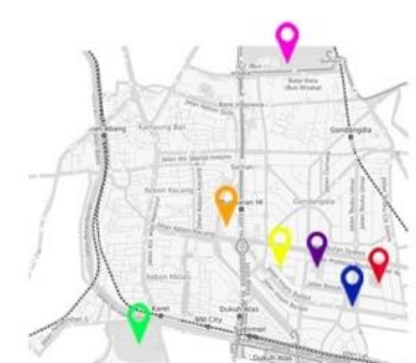

RUANG THRBUKA HIJAU Ptpu bivak t. panarukan $\boldsymbol{\theta}_{\text {T. Suropati }}$

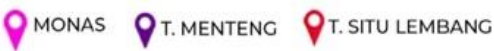

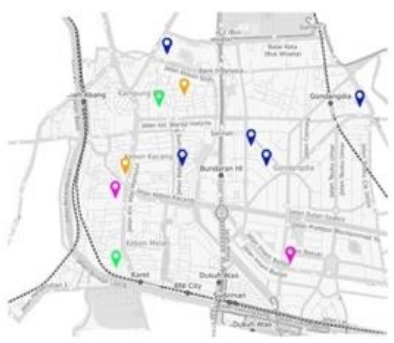

$P_{\text {TK }} \quad P_{\text {SD }}$
PENDIDIKAN $\varphi_{\text {smp }} \varphi_{\text {sma }}$



BASILTAS PEMERIMTAHAN

$\vartheta_{\text {kedutaan }} \vartheta_{\text {bemilu }}^{\text {badengawas }}$ $\vartheta$ ISTANA WAKIL PRESIDEN

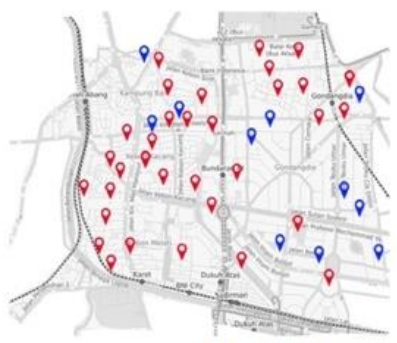

TEMPAT IBADAH

P MAsid/MUSHolla 9 Gereja

Gambar 5. Fasilitas sekitar tapak

Sumber: google maps, dielaborasi, diakses 30 Maret 2021

Sedangkan aksesibilitas pada gambar 6 tapak cukup baik dan pencapaian cukup mudah. Pada sekitar tapak juga dilengkapi halte bus dan pada radius 1000 meter terdapat fasilitas MRT. Sehingga di wilayah ini dapat disimpulkan merupakan wilayah yang sibuk, terutama pada jam kantor.

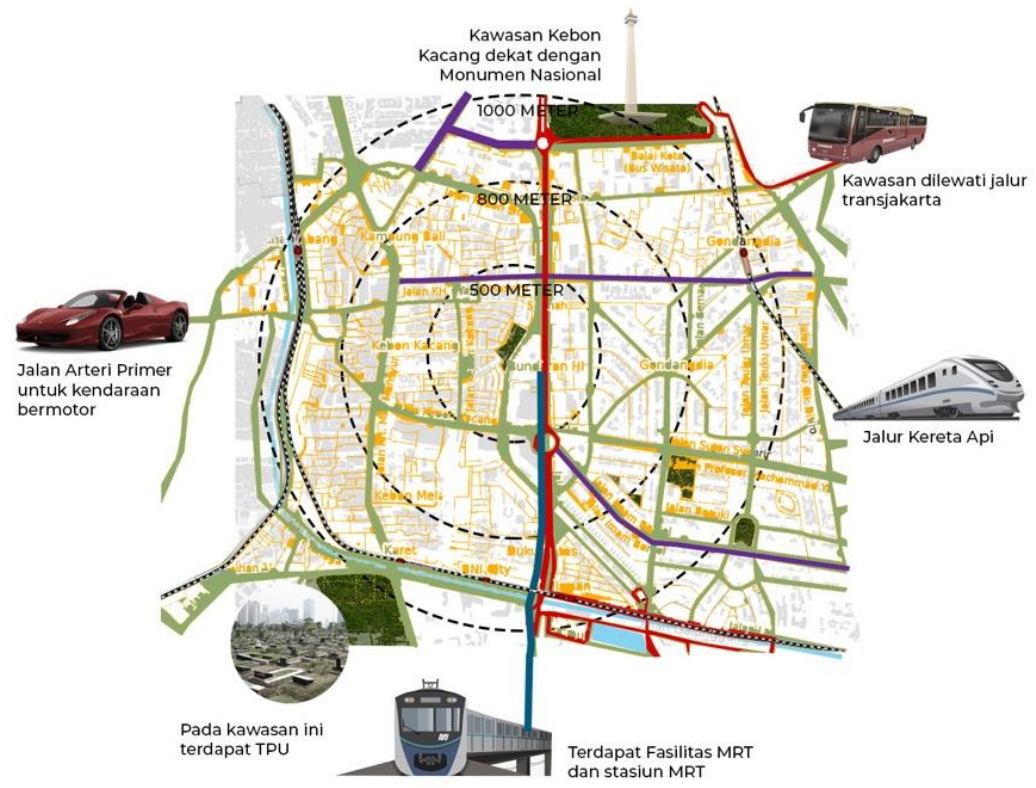

Gambar 6. Aksesibilitas sekitar tapak

Sumber: google maps, dielaborasi, diakses 30 Maret 2021 
Dari hasil analisis tapak ini mempengaruhi pembentukan program pada bangunan. Dimana dari hasil analisis bahwa rumah susun ini berada di kawasan segitiga emas dengan fasilitas yang menegah ke atas dan penghuni rumah susun pun sudah beralih dan didominasi masyarakat menengah ke atas. Sehingga program yang muncul akan memfasilitasi penghuni rumah susun Kebon Kacang dengan standar menengah ke atas. Segala isu yang diselesaikan adalah untuk memberikan kenyamanan berupa fasilitas yang mumpuni serta untuk meminimalisir kegiatan di luar selain rumah susun selama pandemi Covid-19 dan seterusnya. Berikut adalah program utama rumah susun (gambar 7).

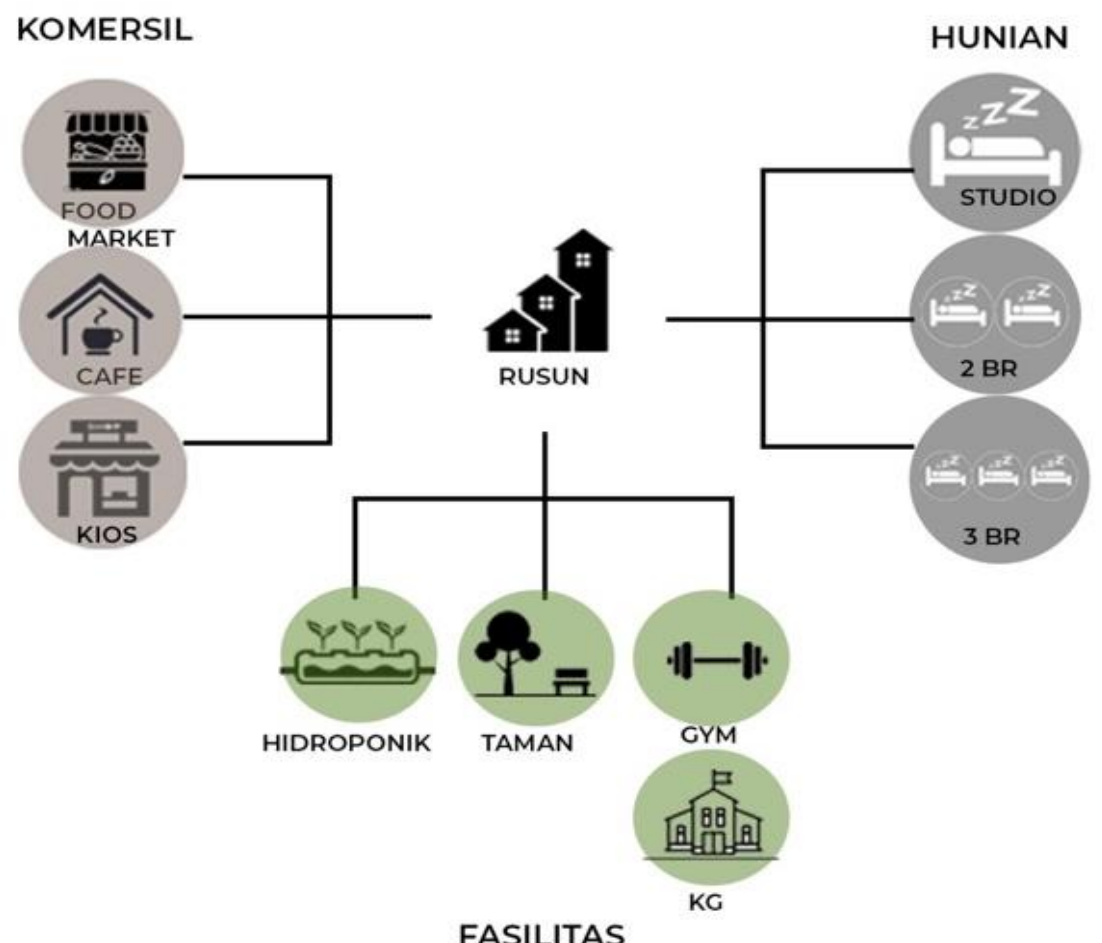

Gambar 7. Program Rumah Susun

Sumber: Penulis, 2021

\section{Penerapan Self-sufficient pada Bangunan}

Pada proyek redesain rumah susun Kebon Kacang ini bertujuan untuk mengubah rumah susun yang lama menjadi lebih hidup mulai dari fasilitasnya sampai ke konsepnya. Dimana konsep desain pada proyek ini menerapkan self-sufficient. Berikut adalah beberapa kriteria yang diterapkan pada bangunan.

Pada gambar 8 terdapat 4 kriteria yang diterapkan pada bangunan. Yang pertama adalah:

a. self food production, dimana pada bangunan mempunyai fasilitas untuk memproduksi makanan sendiri bagi penghuni. Produksi makanan ini menggunakan teknik hidroponik NFT (Nutrient Film Technique) dimana menggunakan media air sebagai media tanam. Beberapa sayuran yang dapat ditanam seperti sawi hijau, brokoli, bayam dan buncis. Beberapa tanaman yang mudah untuk di tanam terutama bagi pemula. Hidroponik ini dihadirkan untuk penghuni agar dapat memenuhi kebutuhan makanan terutama saat pandemi covid-19 untuk meminimalisir kegiatan di luar selain rumah susun dan mengisi kegiatan.

b. Rainwater harvesting yang diletakkan di taman dengan tujuan menggunakan kembali air hujan untuk menyirami tanaman-tanaman yang berada di lantai dasar. Rainwater harvesting menggunakan core beton sebagai media masuknya air dan dilapisi fasad dengan bambu. Tujuan penggunaan bambu juga untuk sebagai media tanam.

c. Green roof menggunakan bak tanaman dengan tujuan menjadi buffer udara panas dan menghasilkan oksigen untuk bangunan rumah susun yang berada di tengah-tengah pusat kota ini. 
d. Green Balcony \& Solid-Void adalah balkon yang produktif. Dimana balkon diisi dengan tanamantanaman yang disusun secara bersilang antar kamar hunian. Pada bangunan juga diterapkan solidvoid yang tujuannya sebagai cross-ventilation.

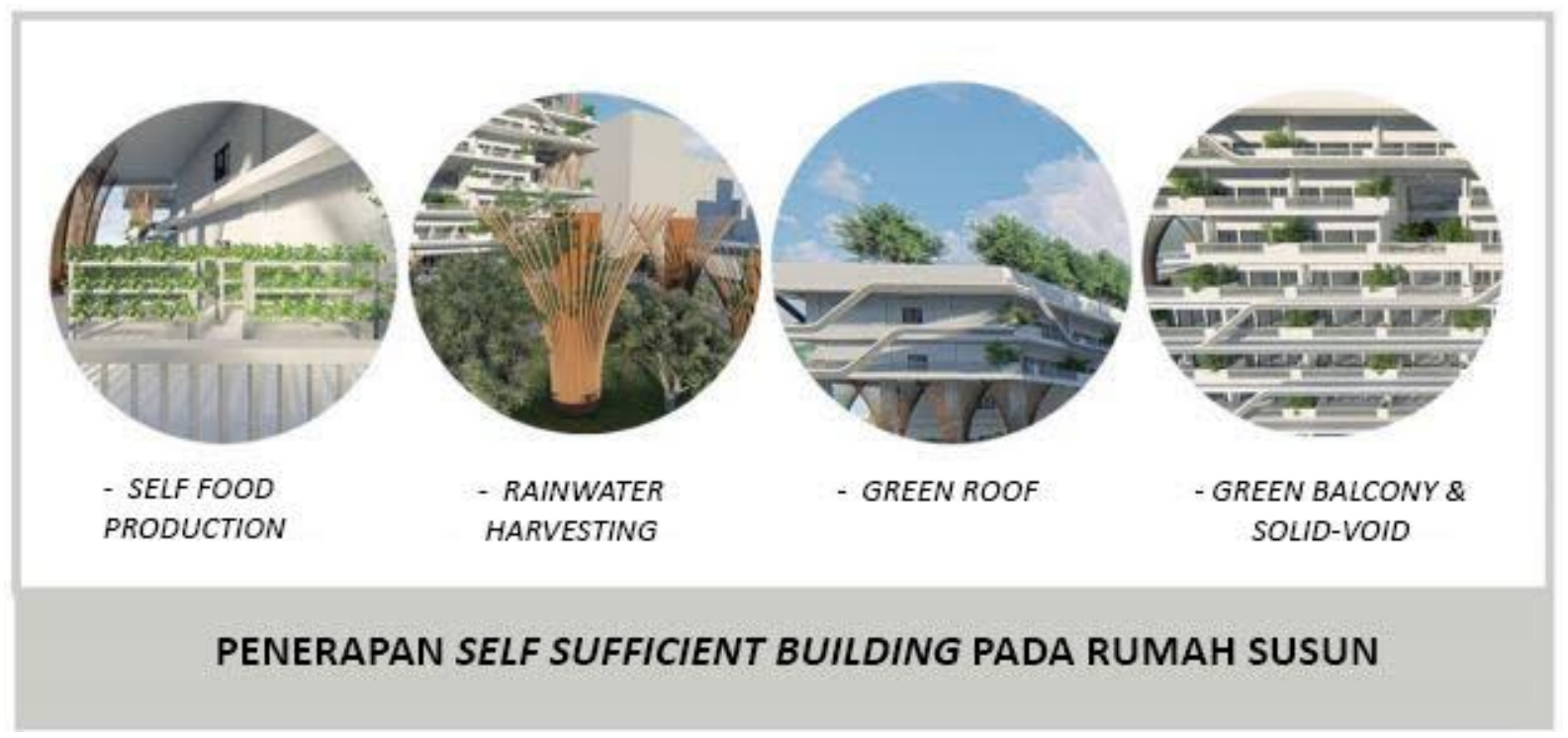

Gambar 8. Penerapan self-sufficient pada rumah susun Sumber: Penulis, 2021

\section{Proses Transformasi Massa}

Massa bangunan hunian harus memperhatikan orientasi matahari, sebab kesensitivan matahari dapat mengganggu kenyamanan penghuni. Pada umumnya orientasi massa yang memanjang lebih cenderung ke arah utara dan selatan sehingga matahari yang di dapat tidak terlalu menyengat.

Massa di bagi menjadi 3 tower untuk menghasilkan hunian dengan tipe double loaded. Tipe double loaded ini dilengkapi dengan single koridor di tengah. Dengan 3 tower ini pada tapak menghasilkan jarak antar tower yang maksimal dan memungkinkan angin untuk tetap bergerak masuk pada masingmasing tower. Sedangkan pada tapak yang memiliki orientasi yang berbeda, dimanfaatkan sebagai RTH (Ruang Terbuka Hijau), dimana RTH sebagai salah satu kriteria rumah susun. RTH ini dimanfaatkan untuk kegiatan sosialisasi antar penghuni, berolahraga seperti lari pagi/sore dan bersepeda, serta untuk jalan-jalan.

Pada massa bangunan ini diterapkan konsep solid-void dengan tujuan untuk menghasilkan crossventilation antar bangunan. Bagian void pada bangunan atau dapat disebut juga dengan green transitional space. Artinya disini bagian void dimanfaatkan sebagai ruang komunal hidroponik dan ruang komunal hijau. Sehingga jadilah terbentuk massa bangunan rumah susun Kebon Kacang yang memiliki 3 tower dengan program hunian, komunal hidroponik, komersial, dan fasilitas penunjang lainnya untuk mewadahi kegiatan dan kebutuhan penghuni rumah susun terutama pada kondisi Covid19 yang senantiasa belum berkurang dan semakin bertambah. 


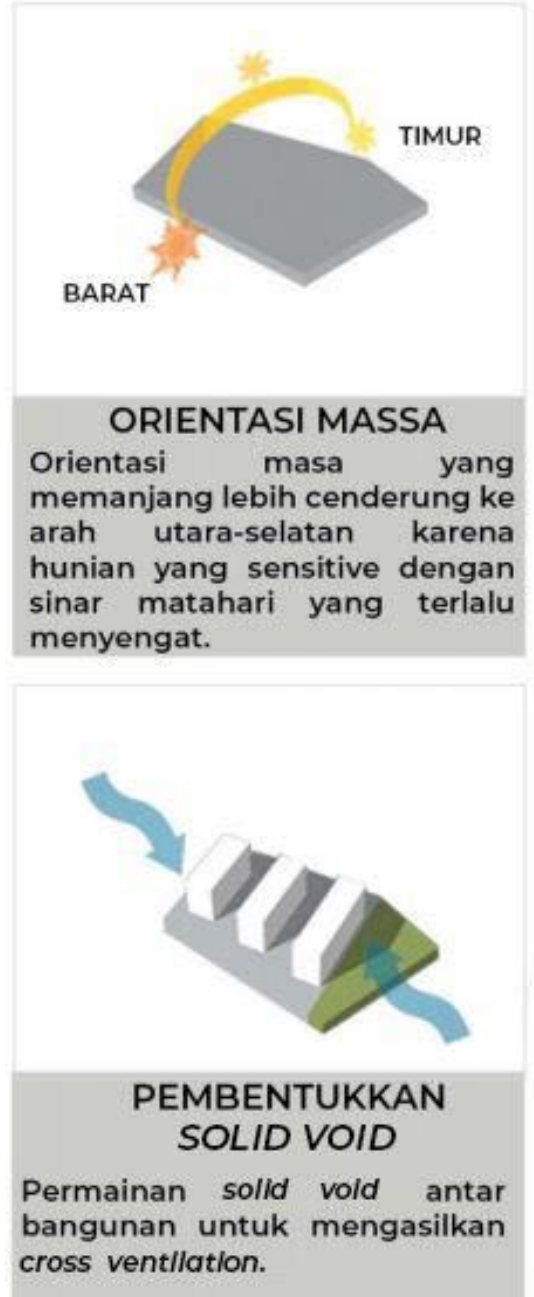

Orientasi masa yang memanjang lebih cenderung ke arah utara-selatan karena hunian yang sensitive dengan sinar matahari yang terlalu menyengat.



\section{FUNGSI VOID}

Pada bagian vold juga diisi dengan kegiatan yakni ruang komunal dan ruang hidroponik.

Gambar 9. Transformasi Massa Sumber: Penulis, 2021

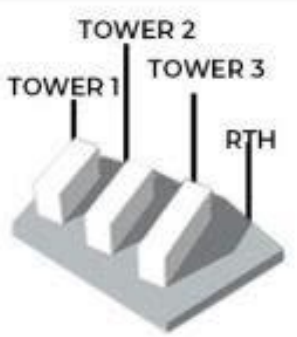

\section{ZONING MASSA}

Ke 3 tower memiliki orientasi yang sama dan pada bagian tapak di kanan dengan orientasi yang berbeda dimanfaat sebagai RTH.

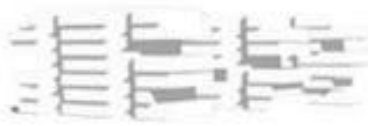

\section{BENTUK AKHIR}

Bentuk akhir gubahan massa bangunan.

Pada bangunan redesain rumah susun Kebon Kacang ini terdapat 3 tower hunian, taman bermain, lapangan basket, dan taman yang dilengkapi rainwater harvesting (gambar 10). 


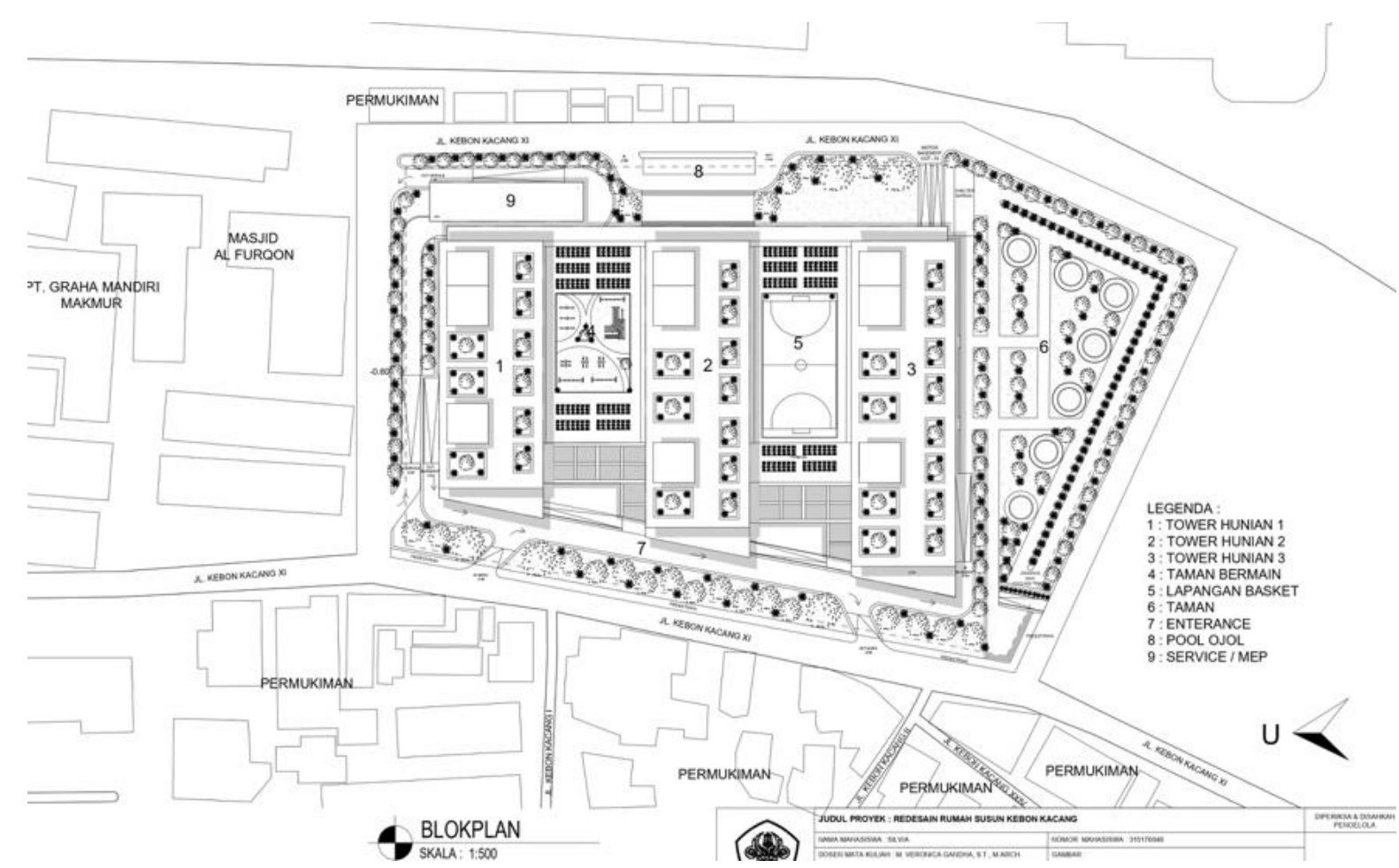

Gambar 10. Denah Blokplan

Sumber: Penulis, 2021

Pada lantai dasar terdapat fasilitas komersial seperti foodmarket, café, coffeeshop, dan kios. Sedangkan pada semi basement terdapat fasilitas penunjang seperti Gym, Aula, KG, dan taman bermain serta lapangan basket (gambar 11).
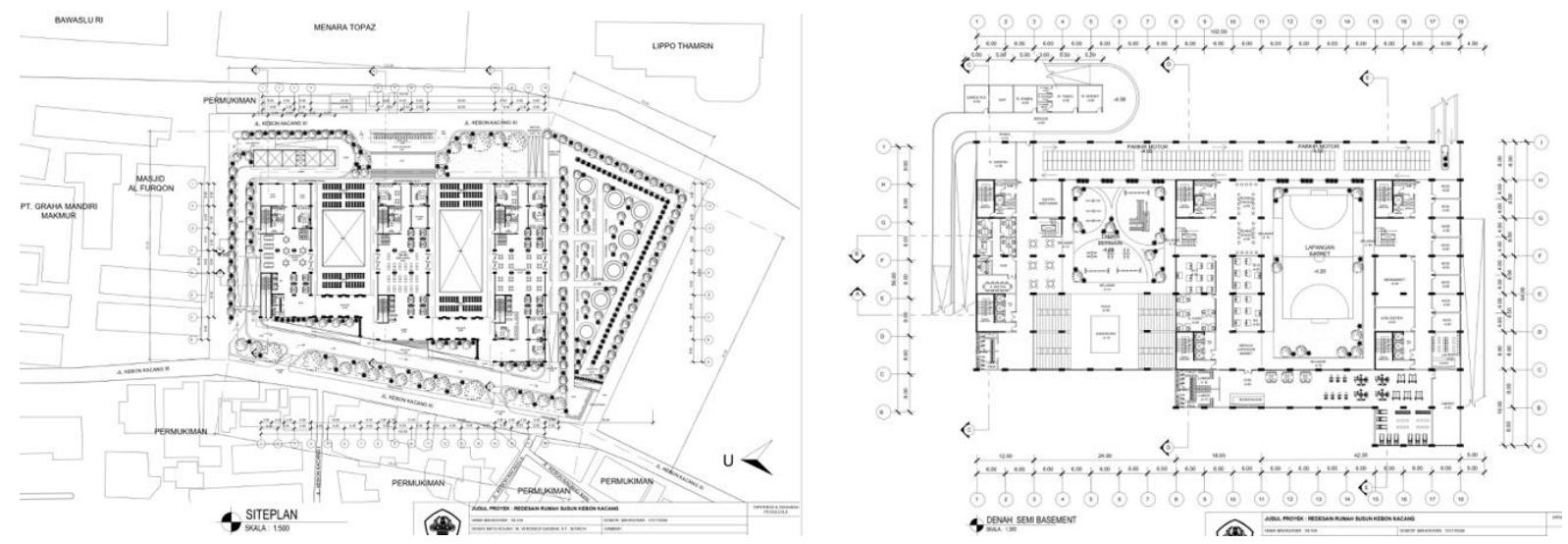

Gambar 11. Denah Siteplan dan Denah Semi Basement Sumber: Penulis, 2021

Pada denah hunian dalam beberapa lantai dilengkapi dengan ruang komunal yang dibagi menjadi dua yaitu ruang komunal hidroponik dan ruang komunal hijau dimana penghuni dapat bersantai dan berkumpul (gambar 12 dan 13). 


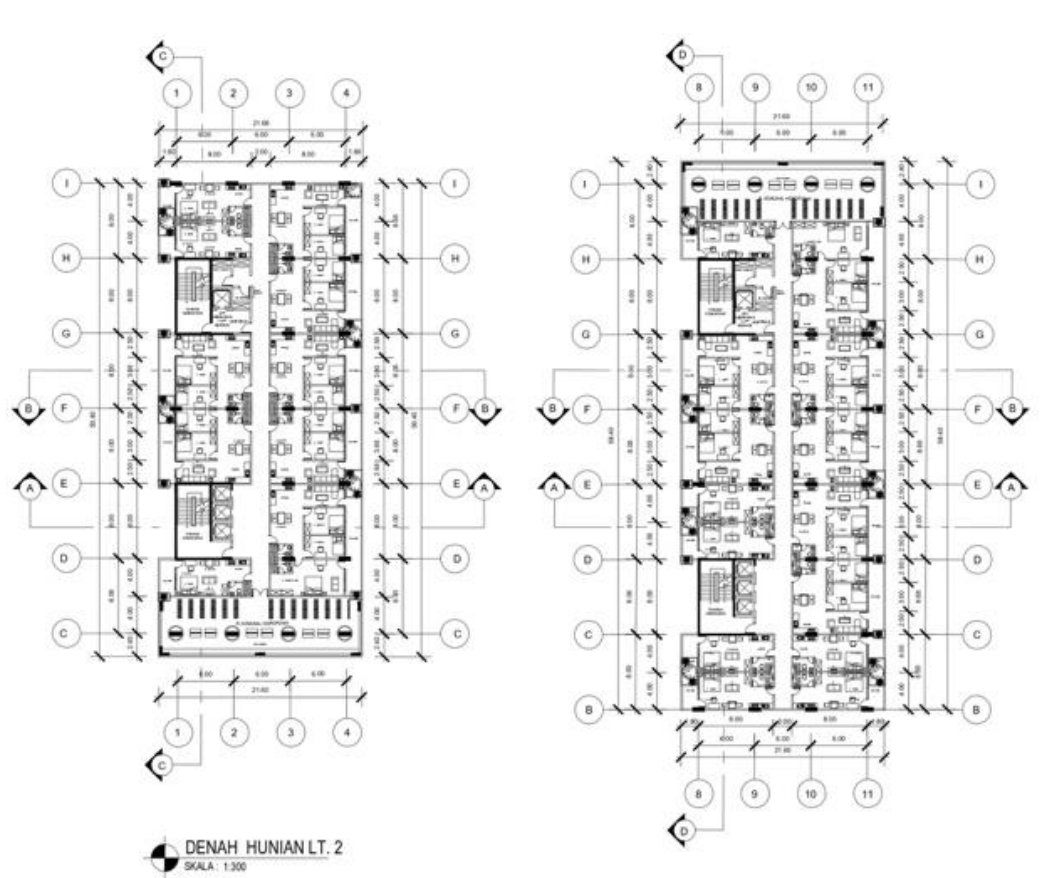

Gambar 12. Denah Tipikal Hunian Sumber: Penulis, 2021

Berikut gambar tampak bangunan (gambar 13) dan beberapa ilustrasi gambar 3D Eksterior (gambar 14) redesain Rumah Susun Kebon Kacang dengan penerapan self-sufficient.

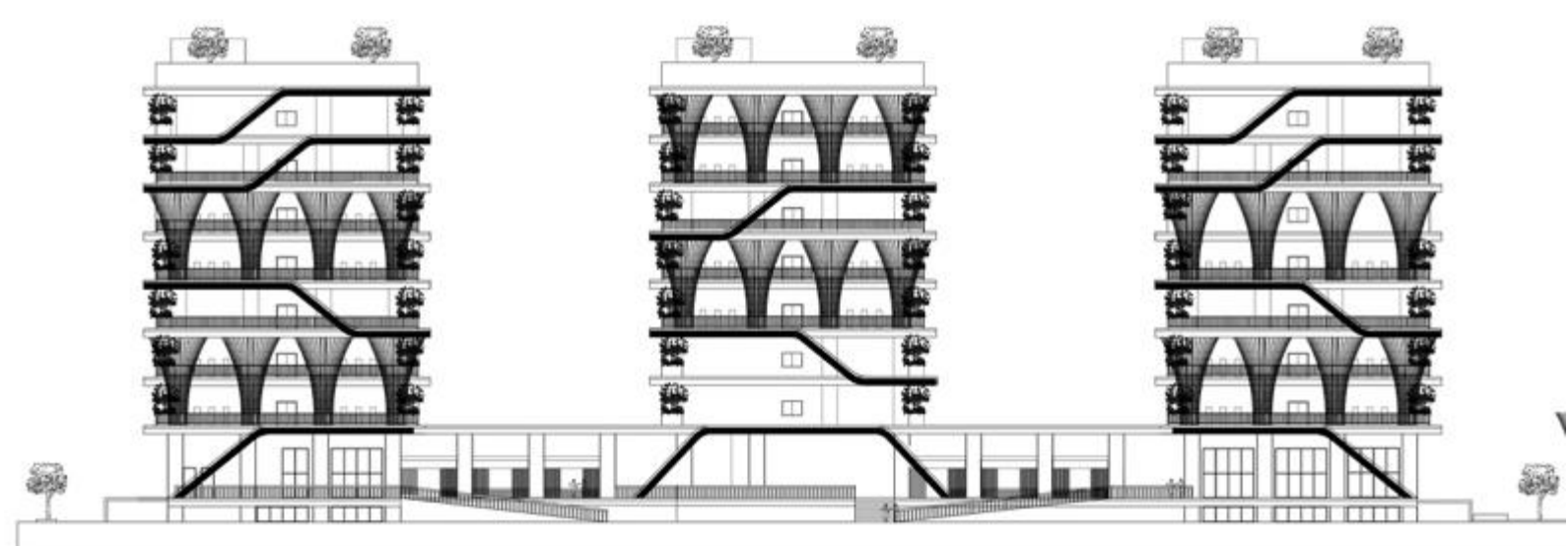

TAMPAK DEPAN

Gambar 13. Tampak depan

Sumber: Penulis, 2021 


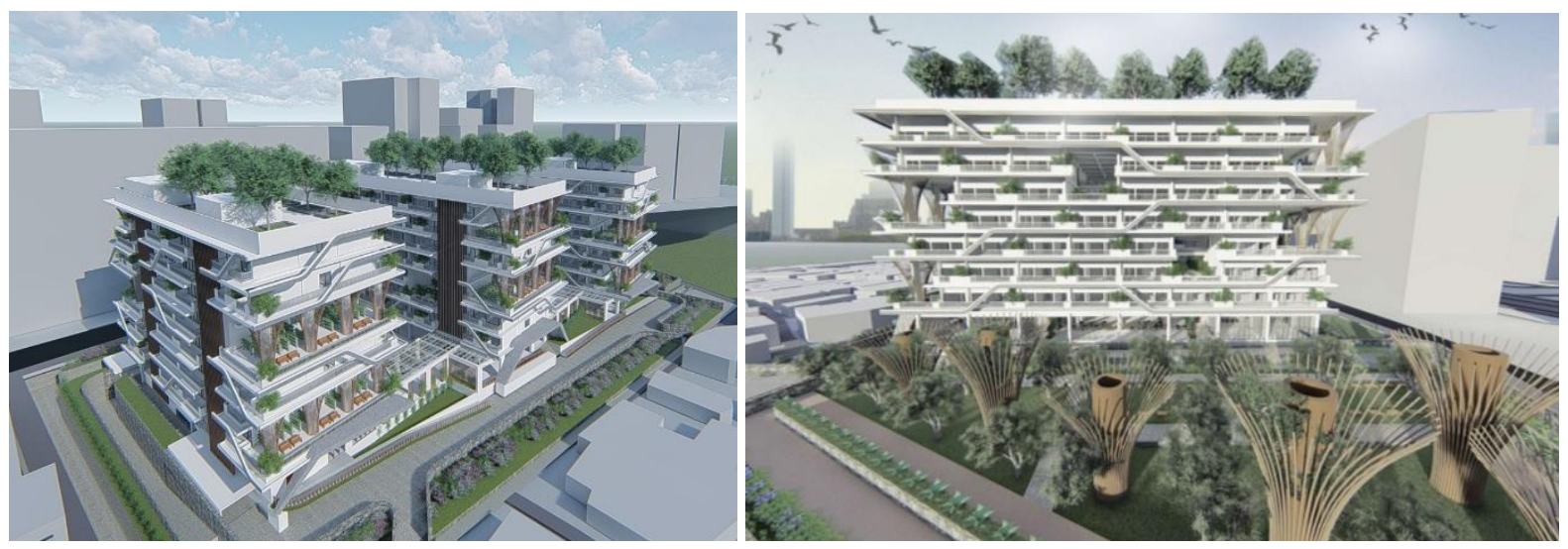

Gambar 14. 3D Eksterior Bangunan

Sumber: Penulis, 2021

\section{KESIMPULAN}

Pada proyek redesain rumah susun Kebon Kacang ini bertujuan untuk menyelesaikan masalah yang terjadi pada rumah susun terkait kondisi masa kini. Dimana pandemi Covid-19 yang mengharuskan perubahan kebiasaan dan aktivitas masyarakat, serta faktor internal rumah susun yang sudah tua dan tidak layak lagi. Dengan menerapkan self-sufficient pada bangunan yang bertujuan untuk menjadikan bangunan mandiri dan mengubah kebiasaan penghuni menjadi lebih mandiri serta memberi fasilitas untuk memenuhi kebutuhan sehari-hari penghuni. Dampak yang dihasilkan juga meliputi lingkungan dan ekonomi. Dengan demikian terbentuklah desain massa dengan permainan solid-void yang tujuannya untuk dijadikan ruang produktif yakni ruang komunal hidroponik dan ruang komunal hijau, serta fungsi lainnya sebagai cross-ventilation antar massa bangunan. Selain itu hadirnya balkon produktif yang ditanami tanaman dan rainwater harvesting yang digunakan kembali airnya untuk menyirami tanaman.

\section{REFERENSI}

Bariah, C. (2020, Maret 21). Pengaruh Corona Terhadap Kehidupan Sosial Masyarakat. Retrieved Mei 31, 2021, from Serambinews.com: https://pengaruh-corona-terhadap-kehidupan-sosialmasyarakat?page=all

Brooks, S. K., Webster, R. K., Smith, L. E., Woodland, L., Wessely, S., Greenberg, N., \& Rubin, G. J. (2020). The Psychological Impact of Quarantine and How to Reduce it: Rapid Review of the Evidence. The Lancet, 395(10227), 912-920. doi:10.1016/S0140-6736(20)30460-8

Carmona, M., Tiesdell, S., Heath, T., \& Oc, T. (2003). Public Spaces - Urban Spaces, the Dimension of Urban Design. Oxford: Architectural Press.

Creswell, J. W. (2013). Qualitative Inquiry \& Research Design: Choosing Among the Five Approaches. Thousands Oaks, CA: Sage Publications, Inc.

de Garrido, L. (2012). Self Sufficient Green Architecture. Barcelona: Instituto Monsa de Ediciones, S.A. Haeckel, E. (1866). Generelle Morphologie der Organismen. Allgemeine Grundzüge der Organischen Formen-Wissenschaft, Mechanisch Begründet Durch die von Charles Darwin Reformirte Descendenztheorie. Berlin: Georg Reimer. doi:https://doi.org/10.5962/bhl.title.3953

Huang, C. W. (2020). Clinical features of patients infected with 2019 novel coronavirus in Wuhan, China. The Lancet, 395(10223), 497-506. doi:10.1016/S0140-6736(20)30183-5

Ichwan, L. A. (2010, Desember). Retrieved Juni 6, 2021, from Pergeseran Fungsi Ruang Publik Selasar Pada Rumah Susun: http://lib.ui.ac.id/file?file=digital/2016-8/20249595-S51560Luthfi\%20Abdillah\%20lchwan.pdf

Perhimpunan Dokter Paru Indonesia. (2020). Panduan Praktik Klinis: Pneumonia 2019-nCoV. Jakarta: Perhimpunan Dokter Paru Indonesia. Retrieved from http://www.rsiibnusina.com/media/file/corona.pdf 
Porta, M. (2008). Dictionary of Epidemiology. Oxford University Press.

Roidah, I. (2014). Pemanfaatan Lahan Dengan Menggunakan Sistem Hidroponik. Jurnal Universitas Tulungagung Bonorowo.

Shang, Y. C. (2009). The Autonomous House: A Bio-Hydrogen Based Energy Self Sufficient Approach. International Journal of Environmental Research and Public Health.

Susilawati, Falefi, R., \& Purwoko, A. (2020). Impact of Covid-19's Pandemic on the Economy of Indonesia. Budapest International Research and Critics Institue (BIRCI-Journal): Humanities, 3(2), 1147-1149. doi:10.33258/birci.v3i2.954

Wang, Z., Qiang, W., \& Ke, H. (2020). A Handbook of 2019-nCoV Pneumonia Control and Prevention. China: Hubei Science and Technology Press. Retrieved from http://fpmpam.org/files/Handbook_2019nCoV.pdf

WHO. (2020, Februari 11). WHO Director-General's remarks at the media briefing on 2019-nCoV. Retrieved Juni 30, 2021, from World Health Organization: https://www.who.intl/dg/speeches/detail/who-director-generals-remarks-at-the-mediabriefing-on-2019-ncov-on-11-february- 2020 
